\title{
Dens invaginatus: case report
}

\author{
Dente invaginado: caso clínico atípico
}

Pedro Carlos da ROCHA NETO'

Lucileide de Castro OLIVEIRA'

Marcilio Dias Chaves de OLIVEIRA ${ }^{2}$

Leão Pereira PINTO ${ }^{1}$

Bruno César de Vasconcelos GURGEL'1

Hébel Cavalcanti GALVÃO'

\begin{abstract}
Dens invaginatus is one of the most frequent malformations in dental elements. It can affect all teeth, even primary and supernumerary ones. It consists of an invagination of the crown surface, which happens during odontogenesis and penetrates the interior of the pulp chamber of the dental elements involved. In some cases, it can reach the apical tooth area. The maxillary lateral incisor is the most common site of occurrence. Due to its complex and variable anatomy, the tooth may present pulp necrosis and open apex, making it difficult to salvage. Oehlers classified them into types I, II, and III according to their complexity. This article reviews the literature and describes the treatment of a maxillary central incisor with type II invagination. The invaginated structure in this case detached due to various instrumentations during the change of dressing phase, facilitating root canal filling. In conclusion, this case shows that many methods are capable of removing the invaginated area of a dens invaginatus type II.
\end{abstract}

Indexing terms: Endodontics. Pathology. Oral dens in dente.

\section{RESUMO}

O dente invaginado é uma das alterações de desenvolvimento que mais incide sobre os elementos dentários, podendo acometer qualquer dente existente na cavidade oral, inclusive decíduos e supranumerários. Consiste em uma invaginação da superfície da coroa, que ocorre na odontogênese, que penetra no interior da cavidade pulpar dos elementos dentários envolvidos, podendo chegar, em algumas situações, à região apical. O incisivo lateral superior permanente é o que apresenta maior envolvimento. Por apresentar uma anatomia complexa e variável, quando diagnosticado, o dente pode apresentar necrose pulpar e rizogênese incompleta, o que torna a sua manutenção muitas vezes de difícil solução. Em 1957, Oehlers classificou-os, conforme sua complexidade, em tipos I, II e III. Foi realizada uma revisão da literatura e descrito o tratamento de um incisivo medial superior com invaginação tipo II, cuja estrutura invaginada se desprendeu devido às várias instrumentações durante as trocas de curativo, o que facilitou sua obturação. Pudemos concluir com este caso a viabilidade, através de diversos métodos, da remoção da porção invaginada no tratamento de dentes invaginados tipo II.

Termos de indexação: Endodontia. Patologia bucal. Dens in dente.

\section{INTRODUCTION}

Dens invaginatus is a developmental change that may affectany dental element in the oral cavity, including permanent, deciduous, and supernumerary teeth, and the maxillary lateral incisor is the most common site of occurrence ${ }^{1-4}$. It involves an invagination of the crown surface that penetrates the pulp cavity of dental elements, sometimes reaching the apical region ${ }^{3}$. According to many authors, the incidence varies from 0.04 to $10 \%{ }^{1,3,5-9}$. This anomaly is caused by the folding of the dental papilla, which allows the invagination of the internal epithelium of the enamel organ during dental development before these tissues calcify2-6,9-19. Many causative mechanisms have been proposed, but no consensus was reached ${ }^{1-3,5,7,20}$. The plausible etiologies relate to a delay or stimulation of the focal growth in certain areas of the tooth germ, localized increase in external pressure, excessive folding of the internal epithelium of the enamel organ towards the interior of the dental papilla during tooth germ formation, inadequate bone development and consequent constriction of the arch on the enamel organ, external trauma, infections, nutritional factors, and genetic factors ${ }^{1-4,11-12,15,20-22}$.

\footnotetext{
${ }^{1}$ Universidade Federal do Rio Grande do Norte, Curso de Odontologia, Programa de Pós-Graduação em Patologia Oral. Av. Senador Salgado Filho, 1787, Nova Descoberta, 59056-000, Natal, RN, Brasil. Correspondência para / Correspondence to: PC ROCHA NETO. E-mail: peter_charlez@hotmail. com>.

${ }^{2}$ Universidade Federal do Rio Grande do Norte, Curso de Odontologia. Natal, RN, Brasil.
} 
This developmental change has been given many denominations in addition to dens invaginatus, the most accepted term nowadays: dens in dente, odontoma invaginatus, dilated composite odontoma, tooth inclusion, dentoid in dente, gestant anomaly, tooth in tooth, and telescopic tooth ${ }^{1,3,5,8,10}$. Clinically, the affected tooth may seem normal; may have a larger mesiodistal dimension of the coronal cervical third than the incisal third; may have a large crown with a prominent cingulum with a central foramen or bifid cingulum; and some may have a conical crown $^{5-6,10,12,21,23}$. Often they are associated with other dental changes and many syndromes ${ }^{2,23}$. An invagination may be covered by enamel, dentin, and cement layers, radiographically mimicking a smaller tooth inside the affected tooth, justifying the denomination dens in dente $1,3,8,10,21,23$. Diagnosis of an invaginated tooth is based on the clinical examination of coronal changes and radiographs. The characteristic radiograph image confirms the diagnosis 1,10 . Frequently, invaginated teeth are only identified when a professional radiographs a necrotic pulp that caused abscesses and fistulas and finds the anomaly ${ }^{1,21,23}$. Whenever anatomical changes are found on the crown of a dental element, it is important to radiograph the tooth to determine whether an invagination is present $t^{1,16,21}$.

In 1957, Oehlers ${ }^{14}$ classified dens invaginatus into three types: type I, consisting of invagination limited to the crown of the dental element; type II, consisting of an invagination that extends toward the apex, beyond the cement-enamel junction, without reaching the periodontal membrane or apical tissues; and type III, consisting of an invagination that reaches the periodontal membrane or apical tissues, producing a second foramen.

As demonstrated by histological studies, the thin, hypomineralized, and often discontinuous lining of the invagination, which communicates with the pulp tissue, allows it to be attacked by bacteria and irritants that enter through the opening of the invagination, leading to early pulp necrosis and consequently, interruption of root formation $13,6,8,14,16-19,21,23$. Pulp necrosis together with an open apex increases treatment complexity. Thus an early diagnosis is necessary to provide preventive treatments.

The complex anatomy of dens invaginatus makes treatment nearly always difficult, and often the type of treatment depends on the degree of involvement of the dental element $1,4-6,8,8,10,15-16,18-19,20,23-24$. An early diagnosis allows prophylactic treatment, which consists on sealing the opening of the crown with restorative material to prevent decay of the invagination with consequent involvement of the pulp of the main root, especially in Oehlers cases types
I and $\mid 12,5,8,10,15-16,18,20-21,23$. Even when diagnosed and treated early, regular follow-up is necessary because the prognosis is not entirely favorable, as shown by Lucas et al. ${ }^{25}$, who controlled 80 (13 type I and 67 type II) teeth clinically and radiographically for more than six months after closing the opening on the surface of the dental element early; nine $(11.3 \%)$ treatments failed, all of them involving invagination type II. In other situations, some authors indicate only endodontic treatment of the invagination, leaving the pulp of the main canal intact $1,15-16,20,23-24$. Failing to identify the problem early may lead to invaginated pulp necrosis and periapical lesion. When this happens, depending on the type of invagination, endodontic treatment of the invagination and main canal without surgical intervention may be effective $1,5,7-8,10,15-16,20,23-24$. When the foramen is open, the indicated treatment is apical closure $1,6,16,22$. Another treatment option in such circumstances is the immediate closure of the wide apex through the formation of an apical buffer with appropriate material, such as mineral trioxide aggregate (MTA), collagen, calcium hydroxide, calcium sulfate, and tricalcium phosphate ${ }^{5,6,7,8,9,10,16,17,20,23-24}$. In more complex cases, when the treatment through the canal is unviable, canal treatment is associated with retrograde filling 1,2,5,10,14,22-23,25-26. Surgical treatment should only be performed when nonsurgical treatment fails ${ }^{2,19}$. Azambuja et al. ${ }^{21}$ reported a successful case where only surgical treatment was performed on a tooth with periapical radiolucency and no radiographic pulp chamber. One of the last measures to preserve the dental element is intentional dental reimplantation $15,10,15,16,20$. Nedley \& Powers ${ }^{27}$ described cases of dental element extraction to provide appropriate treatment followed by reimplantation, thereby finding a solution for complex cases of dens invaginatus. Additionally, many dental elements with this anomaly have been surgically removed because treatment was not possible ${ }^{7,10,15-16,18,20,28}$.

The complex internal anatomy of teeth affected by this change often makes treatment complex and challenging. Conventional periapical radiography is our main tool for assessing this complex morphology, but it provides only two-dimensional images of three-dimensional structures. In 2009 cone beam computed tomography became available in dentistry ${ }^{15}$. This system was developed to produce three-dimensional maxillofacial and dental images, greatly benefitting many dental specializations, including endodontics (4). It has many uses in endodontics, including imaging of the morphology of root canals and their locations, and of the root anatomy ${ }^{8}$. Currently, this technique is being used to aid in the treatment of dens invaginatus with good results $4,6,11,18$. 
The treatment of dens invaginatus type II has complications because of its deep invagination, almost reaching the apical region of the dental element, impairing proper cleaning and modeling of the root canal system ${ }^{10,13}$. In these situations some authors suggest removing the invaginated portion for better cleaning and filling with the filler used in root canal systems $s^{2,5,8,17-19,23,25-26}$. This is possible when invagination is surrounded by pulp tissue, hence, not adhered to the entire extension of the root walls, bound only by the cervical portion. The invagination can be removed with high-speed carbide or diamond burrs, Gattes-Glidden burrs, Long-Neck burrs, Mueller burrs, ultrasonic tips, and manual files $5,7,13,17,23$. According to Rodekirchen et al. ${ }^{10}$, Girsch \& McClammy ${ }^{13}$, Kristoffersen et al. ${ }^{18}$, Azambuja et al. ${ }^{21}$. Bishop\& Alani ${ }^{23}$, and Sathorn \& Parashos $^{26}$, a surgical microscope is very helpful in the treatment of dens invaginatus, both for proper access and invagination removal.

Some authors, such as Ozbas et al. found that removal of root canal invagination can increase the fracture risk of thin root walls. In these situations, clinical measures that can strengthen the remaining structure are indicated.

The objective of this work was to report an atypical, nonsurgical treatment of a dens invaginatus Oehlers type $\mathrm{II}^{14}$.

\section{CLINICAL CASE}

A 10-year-old female patient was referred to the endodontics department of the Federal University of Rio Grande do Norte for endodontic treatment of the left maxillary central incisor because of a fistula. Radiographs showed the existence of a radiolucent apical area, incomplete root formation, and invagination Oehlers type III4 (Figure 1). Tooth vitality was then tested with the Endo-Frost Roeko spray (Coltène/Whaledent Inc., Cuyahoga Falls, Ohio) and hot gutta-percha stick, confirming pulp necrosis.

The diagnosis was followed by apexification with calcium hydroxide paste and filling of the root canal by vertical condensation of gutta-percha and endodontic cement. Access preparation revealed two openings, one of the invagination and another of the main canal. Once access was achieved, we proceeded with odontometrics and chemical and mechanical preparation of the canal and invagination. The accessible portion of the main canal was instrumented and irrigated with a $5 \%$ solution of sodium hypochlorite (Farmafórmula Farmácia de Manipulação, Rio Grande do Norte, Brazil) followed by filling with the intracanal dressing. In these situations it is almost impossible to completely clean the main root canal because of the invagination, so we used laboratory-grade calcium hydroxide paste (Vetec Química Fina, Rio de Janeiro, Brasil) to dress the canal, using saline as vehicle (Glicolabor Indústria Farmacêutica Ltda., São Paulo, Brazil) and the opacifier iodoform (Inodon Laboratórios, Rio Grande do Sul, Brasil). This dressing was changed weekly for a month (Figure 2). Then, using the vehicle polyethylene glycol (Calen - S.S. White artigos dentários Ltda., Rio de Janeiro, Brazil), the calcium hydroxide paste was changed every two weeks for three months and then monthly until the radiolucent area disappeared and a barrier of mineralized tissue appeared in the apical region. All this process lasted approximately twelve months, when the root canal was filled by the technique mentioned earlier. In this session, after isolating the dental element with a rubber dam, the temporary sealant was removed with a high-speed spherical burr, and the root canal dressing, with irrigation and a $\mathrm{K}$ file no. 80 (Maillefer, Ballaigues, Switzerland), confirming the formation of an apical barrier (Figure 3). During dressing removal, the invaginated portion detached from the canal, falling on the rubber dam and freeing the main canal (Figure 4). This facilitated the filling of the root canals. Given the situation, we decided to fill the canal using the mixed condensation technique, that is, associating lateral and vertical condensation. A rolled cone was created and its fit in the canal verified radiographically.

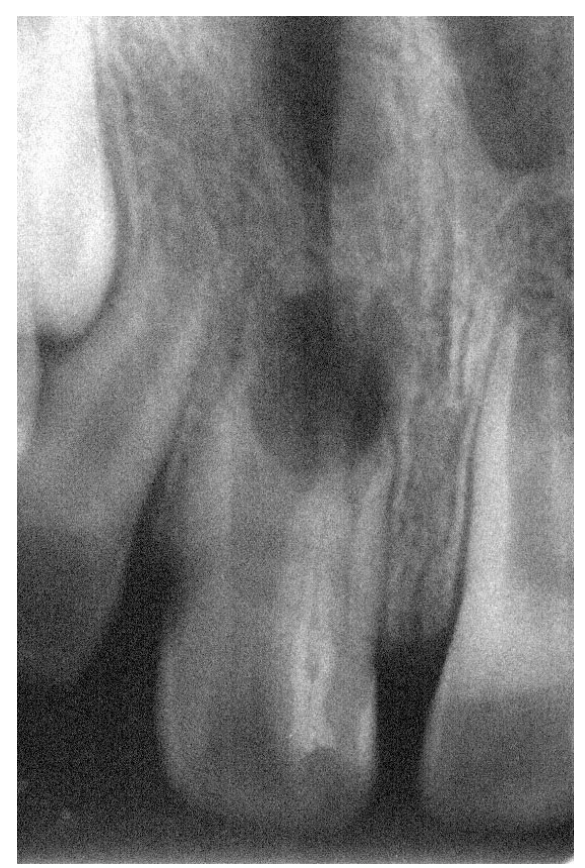

Figure 1. Initial radiograph 
Since the canal was wider in the mesiodistal sense, a radiograph showed that the cone could not completely fill the canal. Another rolled cone was added, and a radiograph showed better filling of the canal. Before placing the selected filler in the canal, the apex was buffered with a thick paste of calcium hydroxide and saline (Figure 5), introduced with a Paiva plugger with a diameter compatible with that of the canal. The objective of this plugger is to avoid leakage of the filler during vertical condensation since the barrier of mineralized tissue that formed can be irregular and contain crevices $^{27}$. After this procedure, the selected cones were lined with endodontic cement based on resin and calcium hydroxide, Sealer 26 (Dentsply, Rio de Janeiro, Brazil) and placed inside the canal. Once the main cones were positioned, the pulp cavity was filled with secondary cones lined with cement, which were then heat-plastified and vertically condensed using a Paiva plugger with a diameter compatible with that of the canal until the material was well adapted to the apical barrier. A radiograph confirmed that the canal was entirely filled (Figure 6). The pulp chamber was then cleaned using cotton soaked with xylol, and the canal opening was sealed with reinforced zinc oxide/eugenol cement (IRM - Dentsply, Rio de Janeiro, Brazil), readying the tooth for the final restoration.

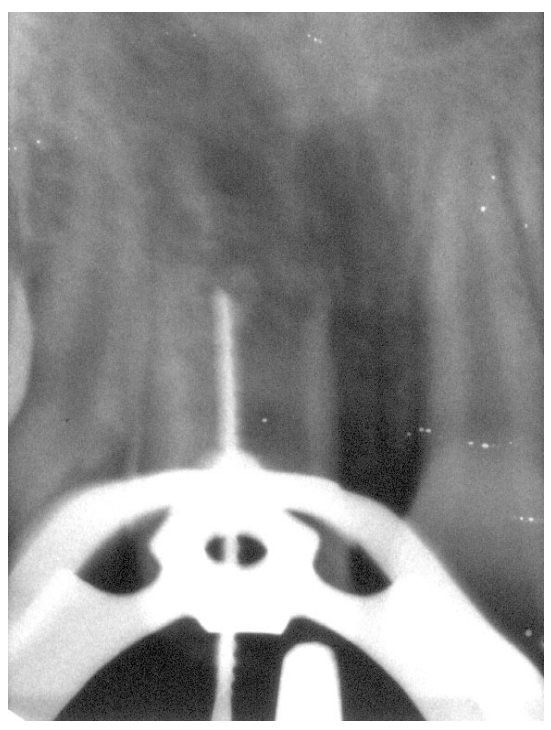

Figure 3. Formation of the apical barrier confirmed.

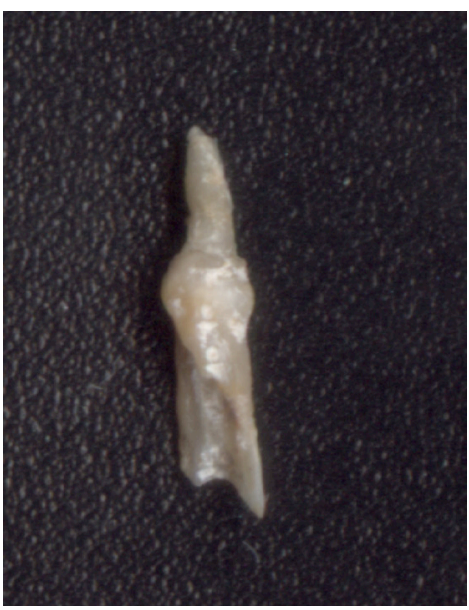

Figure 4. Detachment of the invagination.

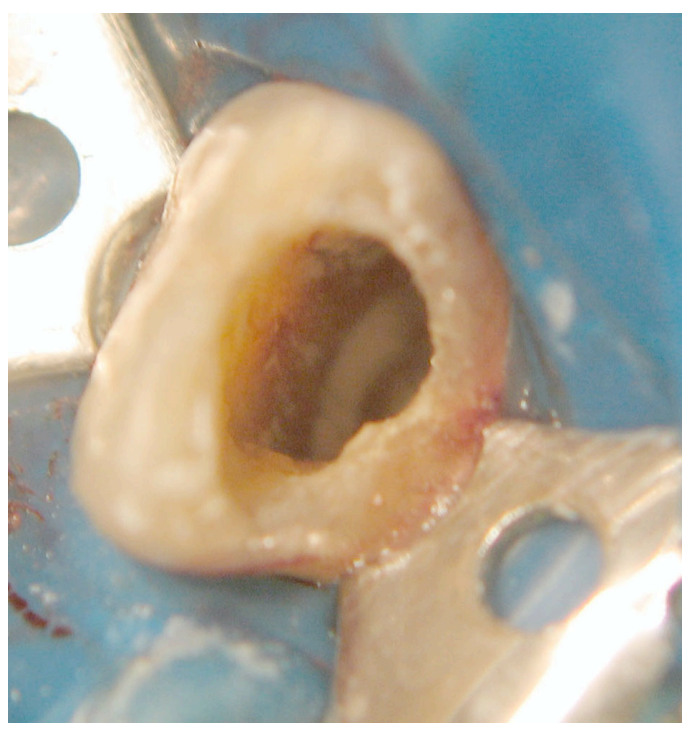

Figure 5. Apical calcium hydroxide buffer. 


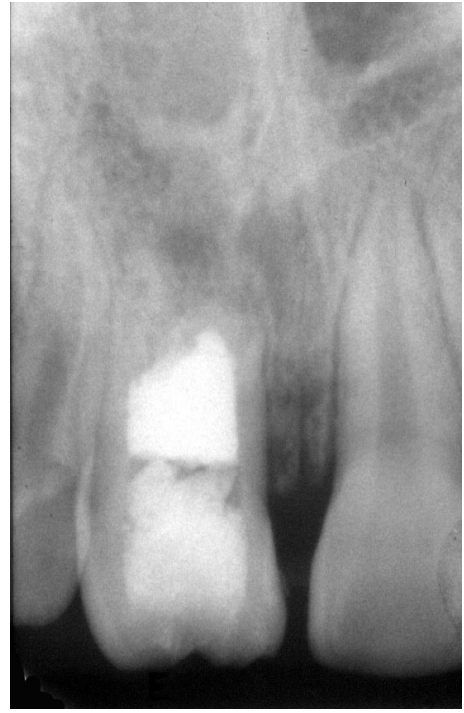

Figure 6. Final radiograph.

\section{DISCUSSION}

Some authors affirm that dens invaginatus is the most common deformation in human teeth ${ }^{22,28}$. Many also affirm that the maxillary lateral incisors are the most common sites of this deformity, followed by the maxillary central incisors ${ }^{1,2,5,8,12,16}$. The tooth treated and presented in this article is a maxillary central incisor.

According to Oehlers ${ }^{14}$, dens invaginatus are classified into three types. Although type II is hard to treat, the treatment is achieved almost always endodontically, like in the present case $e^{5-8,10,20}$.

Most clinical case studies of dens invaginatus involve a necrotic pulp $5-7,8,12-17,20-23,25$, and many have incomplete root formation ${ }^{5-6,8,11,18,20,22,29}$. Both situations were present in the study tooth.

The diagnosis of these entities usually happens when patients look for a professional to treat acute pulpitis $5,7,29$, acute periapical abcess $5,14,16,18,29$, or presence of a fistula related to the affected tooth ${ }^{1,8,25}$. In other situations, the invaginations are discovered during routine examinations 5,20 . The study case was discovered during a routine examination where the professional noticed the presence of a fistula on the bottom of the sac, at the height of the apex of the dental element, which allowed radiographic detection of a dens invaginatus.

When the pulp of the main canal is necrotized, the treatment becomes more complex and challenging because of the difficulty caused by the invagination of cleaning the main canal thoroughly ${ }^{7,17}$. Cleaning and disinfection of the inaccessible regions in these situations can be facilitated by the use of calcium hydroxide dressings in the form of paste associated with abundant irrigation with sodium hypochlorite solutions of various concentrations $1,5,6,8,14,20$. Calcium hydroxide has a number of positive properties, especially because of its highly alkaline $\mathrm{pH}$, such as stimulation of the formation of mineralized tissue, strong bactericidal action, and protein denaturation and hydrolysis, facilitating their dissolution by sodium hypochlorite ${ }^{6,20}$. The study case involved repeated calcium hydroxide dressings, which were removed each time with intense irrigation using $5 \%$ sodium hypochlorite solutions, cleaning the irregularities and places not readily accessible by the endodontic instruments because of the invaginated portion. This is the dressing of choice of most authors for the treatment of dens invaginatus $1,5-8,10-11,14-16,19,22,29-30$. The irrigant of choice for most authors is a sodium hypochlorite solution in concentrations of 0.5 to $5.25 \%$ 1,4,6-12,14,16-18,20-22,29. In many dens invaginatus, pulp necrosis occurs early, leaving many of them with incomplete roots $1,17,19,25$. In these situations, it is necessary to induce the formation of a barrier or apical closure before filling the canal system. This measure is widely performed with calcium hydroxide paste. Many authors agree with this type of treatment $1,5,8,9,15-17,20,29$. In the study case, the therapy was performed with calcium hydroxide. The ideal objective was not reached, that is, continuation of root formation. We only achieved simple closure of the apex by the production of hard tissue. The non-continuation of root formation kept the tooth shorter, with thin walls, and therefore, more vulnerable to the forces it is submitted to on a daily basis, which may reduce its stay in the oral cavity.

Invagination in the case of dens invaginatus type II generally occurs inside the pulp cavity, is totally surrounded by pulp tissue, and is not totally adhered to the canal walls. This leads some authors to remove it with burrs, ultrasonic tips, or files $5,7-8,15-17,23$. In the study case, the invagination detached spontaneously probably because of the numerous manipulations with endodontic files during the placement and removal of the calcium hydroxide dressings. This shows that in the cases of dens invaginatus type II, it is possible to carefully remove the invagination to facilitate cleaning, apexification, and filling of the canal system.

Many authors such as Rajini et al. ${ }^{7}$, Paula-Silva et al. ${ }^{8}$, Helvacioglu-Yigit \& Aydemir ${ }^{12}$ Girsch \& McClammy ${ }^{13}$, Lucas \& Lucas $^{25}$, and Sathorn \& Parashos ${ }^{26}$, affirm that the best techniques to fill dens invaginatus are those that use heat-plastified gutta-percha. This is because these techniques facilitate the filling of irregularities presented by these teeth ${ }^{30}$. 
In principle, the filling technique used on the cited canal would be heated vertical condensation, which was changed due to the unexpected detachment of the invagination. Hence, after this occurrence, we decided to fill the canal using lateral condensation associated with vertical condensation.

Teeth in these situations present thin and fragile root walls, often remaining in the dental arch not for very long9. Yet it is critically important to maintain the tooth for as long as possible, especially in young patients, to maintain the space until occlusion is established ${ }^{11}$.

Although family members of the study patient were informed of the need of periodical follow-up, the patient stopped visiting us. We failed to contact the patient using the information available in the medical record.

\section{REFERENCES}

1. Gesteira MFM, Corbacho MM, Vidal SMM, Pastor IMO. Terapia endodôntica em dens invaginatus: relato de um caso. RCI Med Biol. 2007;6(3):360-70.

2. Ozbas H, Subay RK, Ordulu M. Surgical retreatment of an invaginated maxillary central incisor following overfilled endodontic treatment: a case report. Eur J Dent. 2010;4(3):324-8.

3. Alani A, Bishop K. Dens invaginatus. Part 1: classification, prevalence and aetiology. Int Endod J. 2008;41(12):1123-36. doi: 10.1111/j.1365-2591.2008.01468.x

4. Vier-Pelisser FV, Pelisser A, Recuero LC, Só MVR, Borba, MG, Figeiredo JAP. Use of cone beam computed tomography in the diagnosis, planning and follow up of a type III dens invaginatus case. Int Endod J. 2012;45(2):198-208. doi: 10.1111/j.13652591.2011.01956.x

5. Gharechahi M, Ghoddusi J. A nonsurgical endodontic treatment in open-apex and immature teeth affected by dens invaginatus using a collagen membrane as an apical barrier. J Am Dent Ass. 2012;143(2):144-8.

6. Kaneko, T, Sakaue H, Okiji T, Suda H. Clinical management of dens invaginatus in a maxillary lateral incisor with the aid of conebean computed tomography: a case report. Dent Traumatol. 2011;27(6):478-83. doi: 10.1111/j.1600-9657.2011.01021.x

7. Rajini MA, Kaiwar A, Meena N, Kumar RA, Shetty A, Naveen DN, et al. Nonsurgical endodontic treatment of type II dens invaginatus. J Conserv Dent. 2009;12(2):73-6. doi: 10.4103/0972-0707.55622

8. Paula-Silva FWG, Rocha CT, Flores DSH, Nelson-Filho P, Silva $L A B$, Queiroz AM. Root canal treatment of an immature dens invaginatus with apical periodontitis: a case report. J Dent Child. 2011;78(1):66-70.

9. Fayazi S, Bayat-Movared S, White SN. Rapid endodontic management of type II dens invaginatus using an MTA plug:

\section{CONCLUSION}

Despite the difficulty in treating and maintaining dens invaginatus, the study case had a successful outcome. This case showed the viability of removing the invaginated portion for better cleaning and filling of the root system behind dens invaginatus.

\section{Collaborators}

ROCHA NETO PC, OLIVEIRA LC, OLIVEIRA MDC treated the clinical case, searched the literature, and wrote the manuscript. PINTO LP, GURGEL BCV, GALVÃO $\mathrm{HC}$ supervised the writing and reviewed the manuscript.

a case report. Spec Care Dentist. 2013;33(2):96-100. doi: 10.1111/j.1754-4505.2012.00300.x

10. Rodekirchen $\mathrm{H}$, Jung $\mathrm{M}$, Ansari $\mathrm{F}$. Dens invaginatus type II: case report with 2-years radiographic follow-up. Oral Surg Oral Med Oral Pathol Oral Radiol Endod. 2006;102(4):e121-5. doi:10.1016/j.tripleo.2005.10.064

11. Patel S. The use of cone beam computed tomography in the conservative management of dens invaginatus: a case report. Int Endod J. 2010;43(8):707-13. doi: 10.1111/j.13652591.2010.01734.x

12. Halvacioglu-Yigit $D$, Aydemir S. Endodontic treatment of type II dens invaginatus in a maxillary lateral incisor: A case report. Case Report Dent. 2012;2012:4. doi: 10.1155/2012/153503

13. Girsch WJ, McClammy TV. Microscopic removal of dens invaginatus. J Endod. 2002;28(4):336-9.

14. Oehlers FA. Dens invaginatus (dilated composite odontome) 1. Variations of the invagination process and associated crown forms. Oral Surg Oral Med Oral Pathol. 1957;10(11):1204-18.

15. Tsurumachi T, Hayashi M, Takeichi O. Non-surgical root canal treatment of dens invaginatus type 2 in a maxillary lateral incisor. Int Endod J. 2002;35(3):310-4. doi: 10.1046/j.13652591.2002.00450.x

16. Jung M. Endodontic treatment of dens invaginatus type III with three root canals and open apical foramen. Int Endod J. 2004;37(3):205-13. doi: 10.1111/j.0143-2885.2004.00778.x

17. Pai S-F, Yang S-F, Lin LM. Nonsurgical endodontic treatment of dens invaginatus with large periradicular lesion: a case report. J Endod. 2004;30(8):597-600

18. Kristoffesen $\mathrm{O}, \mathrm{Nag} \mathrm{OH}$, Fristad I. Dens invaginatus and treatment options based on a classification system: Report of a type II invagination. Int Endod J. 2008;41(8):702-9. doi: 10.1111/j.1365-2591.2008.01399.x

19. Schmitz MS, Montagner F, Flores CB, Morari VH, Quesada GA, Gomes BP. Management of dens invaginatus type I and open 
apex: report of three cases. J Endod. 2010;36(6):1079-85. doi: 10.1016/j.joen.2010.02.002

20. Steffen $H$, Splieth $C$. Conventional treatment de dens invaginatus in maxillary lateral incisor with sinus tract: one year follow-up. J Endod. 2005;31(2):130-3. doi: 10.1097/01. don.0000137637.94281.82

21. Azambuja TWB, Bercini F, Almeida MG. Dente invaginado: revisão de literatura e apresentação de casos clínicos. Rev Fac Odontol Univ Passo Fundo. 2002;7(2):27-32.

22. Ortiz $P$, Weisleder $R$, Villareal DE, Justus $Y$. Combined therapy in the treatment of dens invaginatus: Case report. J Endod. 2004;30(9):672-4. doi: 10.1097/01. DON.0000121611.19808.AD

23. Bishop K, Alani A. Dens invaginatus. Part 2 : clinical, radiographic features and management options. Int Endod J. 41(12):113754. doi: 10.1111/j.1365-2591.2008.01469.x

24. De Moor R. Dens invaginatus - a challenge in endodontics. Rev Belge Med Dent. 2005;60(1):49-57.

25. Lucas $G V$, Lucas ON. Dens invaginatus: tratamiento en un diente permanente joven. Rev Asoc Dent Mex. 2003; 60(6):229-232.
26. Sathorn C, Parashos P. Contemporary treatment of class II dens invaginatus. Int Endod J. 2007;40(4):308-15. doi: 10.1111/j.1365-2591.2007.01205.x

27. Nedley MP, Powers GK. Intentional extraction and reimplantation of an immature invaginated central incisor. ASDC J Dent Child. 1997;64(6):417-20

28. Seibel VM, Soares RG, Limongi O. Histomorfologia de reparo após tratamento endodôntico em dentes com rizogênese incompleta: revisão da literatura. Rev Sul-Bras Odont. 2006;3(2):37-43.

29. Brkic H, Filipovic-Zore I, Koric N. The treatment options of dens invaginatus complications in children: report of 3 cases. J Dent Child. 2003:70(1):77-81.

30. Özcelik B, Tasman F, Ogan C. A comparison of the surface tension of calcium hydroxide mixed with different vehicles. J Endod. 2000;26(9):500-2.
Received on: 4/6/2012 Final version resubmitted on: 12/4/2013

Approved on: 18/4/2013 
